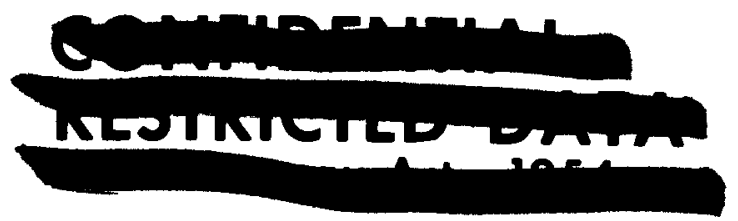
\title{
SINPO-C
}

\section{PARTIAL LENGTH CORE ASSEMBLY VIBRATION TEST}

This report was prepared as an account of work Werther sponsored by the United States Goved States Energy the United States nor the Unurtration, nor any of Research and Development Admor their employees, nor any of ther cokes any subcontractors, or their employees, mes any legal warranty, express or implied, or assumes any legal warranty, exponsiblity for the accuracy, completeness labulity or responssy information, apparatus, product or or usefulness of any moresents that its use would not process disclosed, or represents

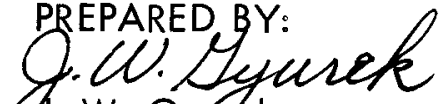

J.W. Gyurek

Reactor Assembly \& Dynamics Experiments

APPROVED:

W. T helen

D. F. Miller, Supervisor

Reacfor Assembly \& Dynamics Experiments की

W. J. Rowan, Manager

Engineering Mechanics

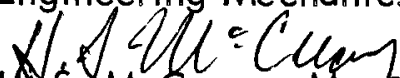

H. McCreary, Managiger

Experimental Enginefering

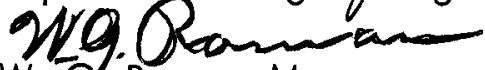

W. G. Roman, Manager

Reactor Engineering, NERVA Project

lec

\section{IMPREGNATED INNER REFLECTOR}

$$
\text { EML-6 }
$$

(Title Unclassified)

Westinghouse Electric Corporation

Astronuclear Laboratory

P.O. Box 10864

Pittsburgh, Pennsylvania 15236

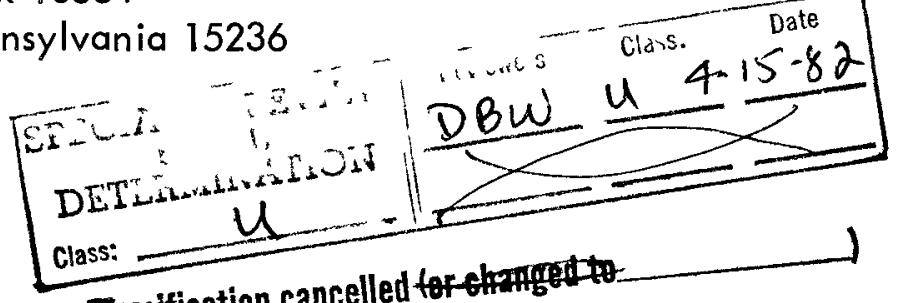

arsification cancelled to anarity b

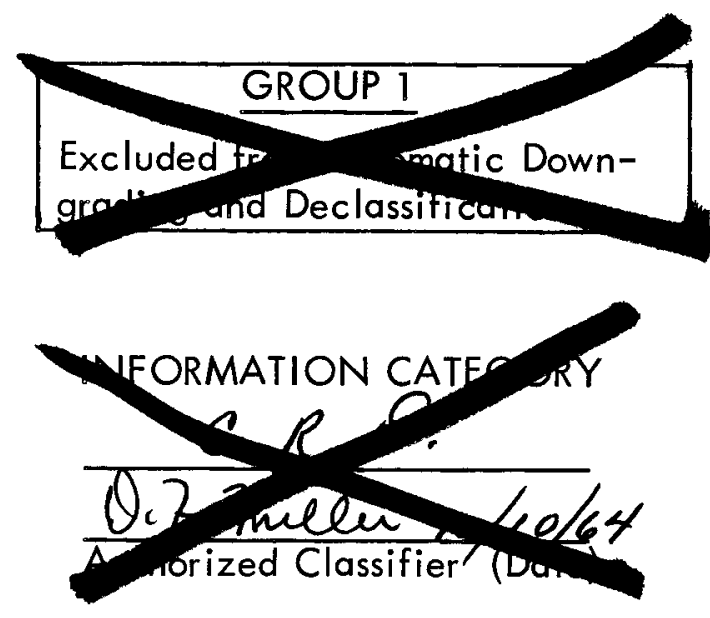




\section{DISCLAIMER}

This report was prepared as an account of work sponsored by an agency of the United States Government. Neither the United States Government nor any agency Thereof, nor any of their employees, makes any warranty, express or implied, or assumes any legal liability or responsibility for the accuracy, completeness, or usefulness of any information, apparatus, product, or process disclosed, or represents that its use would not infringe privately owned rights. Reference herein to any specific commercial product, process, or service by trade name, trademark, manufacturer, or otherwise does not necessarily constitute or imply its endorsement, recommendation, or favoring by the United States Government or any agency thereof. The views and opinions of authors expressed herein do not necessarily state or reflect those of the United States Government or any agency thereof. 


\section{DISCLAIMER}

Portions of this document may be illegible in electronic image products. Images are produced from the best available original document. 


\section{TABLE OF CONTENTS}

1. Summary

Page

2. Objectives

2

3. Conclusions

2

4. Test Specimen

3

5. Test Equipment and Procedure 4

6. Test Results

\section{LIST OF TABLES}

1. Core Breakaway and Lockup

5

2. Core - Innter Reflector Impact

1. Test Setup

7

2. Seal and Plunger Wear 


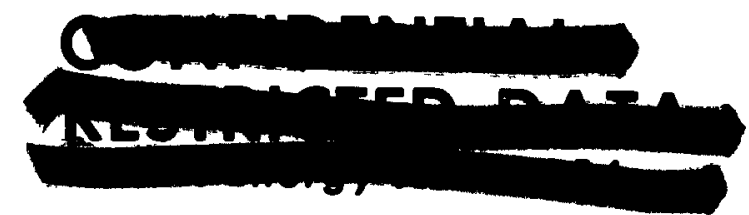

\section{SUMMARY}

Dynamic testing is desireable to determine the response of the specimen to known inputs and to determine the resulting component wear. This test was conducted on a partial length core specimen of components of the latest NRX-A2 design with an impregnated inner reflector for comparison with previous testing of a specimen with an unimpregnated inner reflector (B-5 Test). The specimen consisted of a ten inch long section of inner reflector (impregnated), three rows of the lateral support system and a nine inch long core of individual elements. In both tests the specimen was installed in a support fixture, placed on four oil film slip tables and excited by a electrodynamic thruster. The input and specimen response were monitored by transducers. The data from these tests revealed that the " $G$ " levels that produce core breakaway (initiation of core to inner reflector relative motion), lockup (termination of relative motion) and impact on the inner reflector were lower for this test than those of the B-5 Test (Tables 1 and 2). Both tests, however, reveal that breakaway and lockup "G" levels decrease with increasing frequency.

The average friction force of the system $(1,281 \mathrm{lb})$, as calculated from this test data $_{8}$ compares with the value $(1,205 \mathrm{lb})$ determined from EML-8 static test (reference WANL-TME-962, "Partial Length Core Assembly Static Test - Impregnated Inner reflector - EML-8"。 Except for the core, the same specimen was used in this test and the EML-8 Test. The friction force determined from this test was lower than that of the B-5 Test. The resonant frequency determined from this test is $14 \mathrm{cps}$ as compared with $16 \mathrm{cps}$ for the B-5 Test. The resonant frequency calculated from the results of the static test (EML-8) was $11.8 \mathrm{cps}$. During both this test and the B-5 test, considerable abrasion of the plungers and gouging of the seals occurred at their point of contact. Wear in other areas was insignificant. The wear occurring during this test resulted from higher " $G$ " levels and a greater number of cycles than the actual reactor is expected to experience. Separation of elements was detected at the higher "G" levels (about 4 "G"; There was no breakage of components even after core impacting on the inner reflector. 


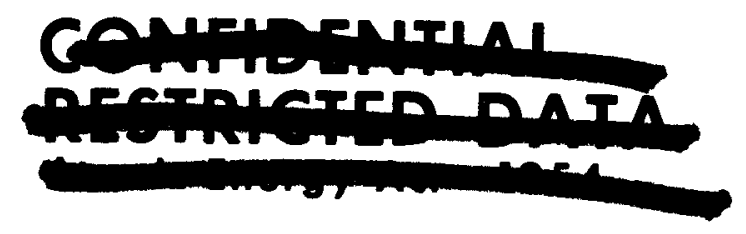

Stronuclear

WANL-TME-980

2. OBJECTIVES

2.1 To determine the input levels required to produce core breakaway, lockup and impact.

2.2 To determine seal segment, plunger and plunger hole wear as a result of dynamic loading.

3. CONCLUSIONS

Response of the specimen to dynamic loading is not appreciably affected by impregnation of the inner reflector. The results of this test were comparable to tests $(B-5)$ conducted on a specimen with an unimpregnated inner reflector.

Both tests show that breakaway and lockup "G" values, at each frequency, are similar with the lockup values tending to be slightly lower. The fact that breakaway, impact and lockup "G" levels are higher for the B-5 test can, in part, be attributed to early seal and plunger wear. This test was conducted with the wear producing, higher "G" level inputs in the latter part of testing to keep early wear-in at a minimum. Wear was not adversely affected by impregnation, as components in areas of contact with the inner reflector were limited to slight polishing. At seal and plunger points of contact, however, wear was extreme as the seals were badly gouged and plungers highly polished at the conclusion of this test. Inspection of the plungers and seal periodically during the test indicated that rapid wearing took place only at inputs greater than 3 " $G$ ", where the larger amplitude occurred.

An equation for the friction force (P) of the lateral support system can be derived from the specimen's equation of motion as follows:

$$
\begin{aligned}
M_{c} X_{c} & =-K\left(X_{c}-X_{I R}\right) \pm P \\
P & =M_{c} X_{c}+K\left(X_{c}-X_{I R}\right) \\
P & =-\frac{W_{c}}{g} \dot{X}_{c}+K\left(X_{c}-X_{I R}\right)
\end{aligned}
$$




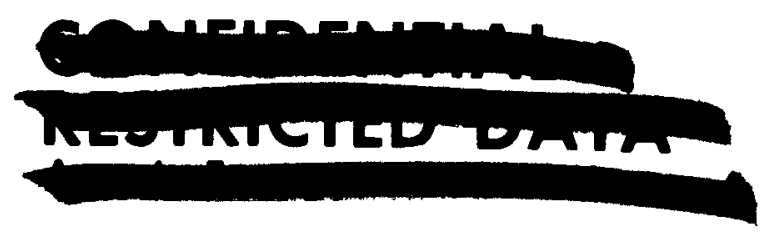

where $W_{c}$ is core weight; $g$ is the gravitational constant; $\ddot{X}_{c}$ is core acceleration; $K$ is system spring constant; $X_{C}$ is core displacement and $X_{I R}$ is inner reflector displacement. The friction force can be determined from the maximum acceleration that can be applied to the system without inducing relative motion. In this case $\left(X_{c}-X_{I R}\right)$ is zero and equation (3) becomes:

$$
P=\frac{W_{c}}{g} \ddot{X}_{c}=W_{c} G
$$

Substituting the average breakaway values in equation (4) gives average friction force values of $1281 \mathrm{lb}$ for this test and $1750 \mathrm{lb}$ for the B-5 test as compared with $1205 \mathrm{lb}$ from the static test - EML-8.

4. TEST SPECIMEN

The test specimen consisted of the following components:

$\begin{array}{lc}\frac{\text { Item }}{\text { Inner Reflector (lmpregnated) }} & \text { Dwg. No. } \\ \text { Seal Segments } & 709 \text { J } 918 \\ & 977 \text { D } 843 \\ & 977 \text { D } 844 \\ \text { Spring Assemblies } & 977 \text { D } 845 \\ & 977 \text { D } 851 \\ \text { Screws } & 977 \text { D } 852 \\ \text { Graphite Plungers } & 945 \text { C } 660 \\ \end{array}$

The core was made up of nine inch lengths of unfueled elements. The core periphery was filled with solid elements and machined to diameter.

The specimen was assembled in a support fixture (Dwg. No. NT 701120). 

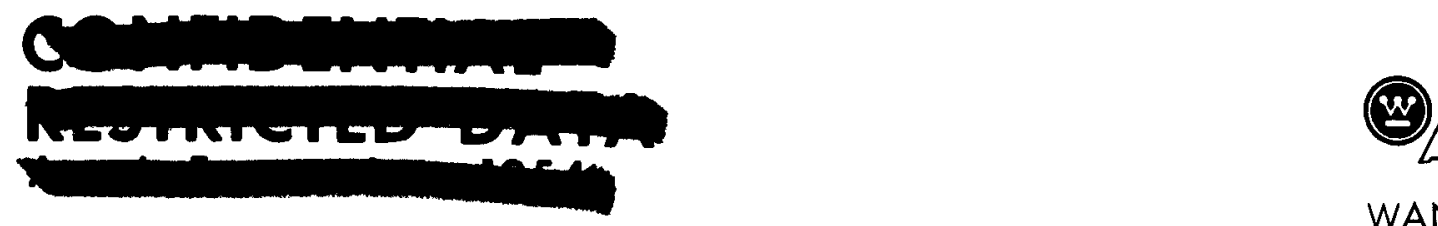

Listronuclear

WANL-TME-980

\section{TEST EQUIPMENT AND PROCEDURE}

The specimen was vibrated using both discrete frequency and sweep frequency inputs to determine the dynamic response of the system. In the discrete frequency tests the specimen was vibrated at 10, 15,20,25,30,35,40, 50 and $100 \mathrm{cps}$. The input acceleration was increased until core relative motion was produced, then decreased until core lockup. At the discrete frequencies of 15 and $20 \mathrm{cps}$, the input acceleration was increased until the core impacted the inner reflector, then decreased. The sweep frequency tests were run from 500, 100 and $50 \mathrm{cps}$ to $5 \mathrm{cps}$ at constant input accelerations of 2, 3 and 4 "G".

The specimen, in a support fixture, was mounted on four oil film slip tables (Figure 1). Dynamic loads were applied through the fixture to the inner reflector by a $10,000 \mathrm{lb}$ electrodynamic vibration exciter. During the test, the core was supported from overhead by means of cords passing through clusters of elements to supporting discs or plates (Figure 1). The dynamic input and the specimen response were monitored by nine transducers. These transducers monitored the following quantities.

a. Drive rod force.

b. Inner reflector acceleration.

c. Inner reflector to reference displacement.

d. Core acceleration.

e. Core to inner reflector displacement.

f. Core to reference displacement.

g. Leaf spring force $\left(180^{\circ}\right.$ from drive direction).

h. Leaf spring force $\left(90^{\circ}\right.$ from drive direction).

i. Drive rod acceleration

The frequency of the input vibration was also recorded. 

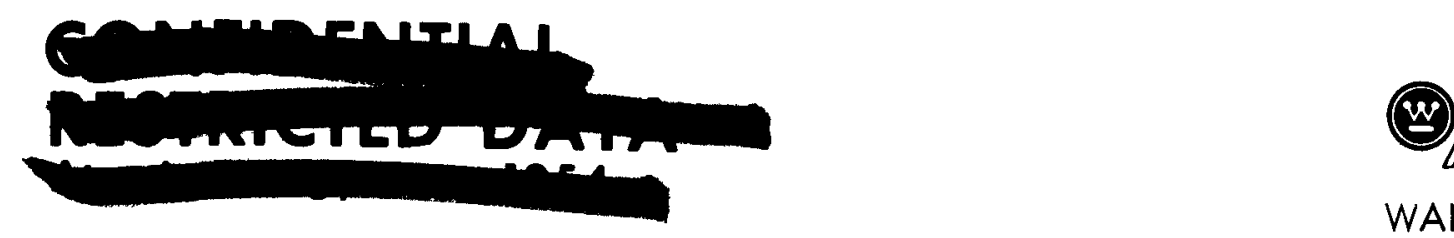

Lstronuclear

WANL-TME-980

At intervals during the test, lateral support springs were removed and the plungers and seals were inspected for wear. Also after the completion of the test, the specimen was disassembled and all components inspected for wear.

\section{TEST RESULTS}

The transducer outputs were recorded on magnetic tape and later transferred to oscillograph paper for data reduction. The core breakaway, lockup and impact points, as determined from examination of the data, are presented in the following tables along with the B-5 test results.

\section{TABLE 1}

Core Breakaway and Lockup

\begin{tabular}{|c|c|c|c|c|c|c|c|c|c|c|c|}
\hline \multicolumn{2}{|c|}{ Frequency (CPS) } & 14 & 15 & 20 & 24 & 25 & 30 & 35 & 40 & 50 & 100 \\
\hline \multirow{2}{*}{$\begin{array}{l}\text { Break- } \\
\text { away "G" }\end{array}$} & EML-6 & - & 2.9 & *3.4 & - & 3.0 & 3.1 & 2.5 & 2.7 & 2.2 & 1.9 \\
\hline & $B-5$ & 4.0 & - & 3.9 & 3.9 & - & 3.5 & 3.5 & 3.3 & 3.0 & - \\
\hline \multirow{2}{*}{$\begin{array}{l}\text { Lock up } \\
\text { "G" }\end{array}$} & $E M L-6$ & - & 2.7 & *3.1 & - & 2.8 & 2.9 & 2.5 & 2.5 & 2.1 & 1.8 \\
\hline & $B-5$ & 3.9 & - & 3.8 & 3.7 & - & 3.5 & 3.4 & 3.3 & 2.9 & - \\
\hline
\end{tabular}

* Average of 5 runs.

\section{TABLE 2}

Core - Inner Reflector Impact

\begin{tabular}{|c|l|c|c|c|c|c|}
\hline \multicolumn{2}{|c|}{ Frequency (CPS) } & 14 & 15 & 20 & 29 & 30 \\
\hline \hline \multirow{2}{*}{$\begin{array}{c}\text { Impact } \\
\text { "G" }\end{array}$} & $\mathrm{EML-6}$ & - & 5.0 & 5.7 & 4.0 & - \\
\cline { 2 - 7 } & $\mathrm{B}-5$ & 6.2 & - & 6.75 & - & 7.2 \\
\hline
\end{tabular}




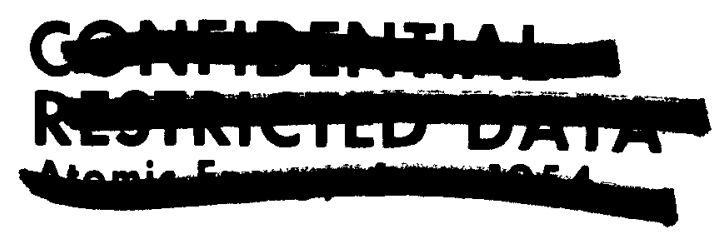

Further examination of the data revealed no unusual reaction of the specimen to the dynamic loading. Examination of plungers and seals at intervals during the test and after specimen disassembly revealed considerable wear had taken place during the latter runs of the test. Examples of this wear are shown in Figure 2. At the completion of the test, 83,000 cycles had been applied to the specimen, of which approximately $50 \%$ would have been with relative motion. 

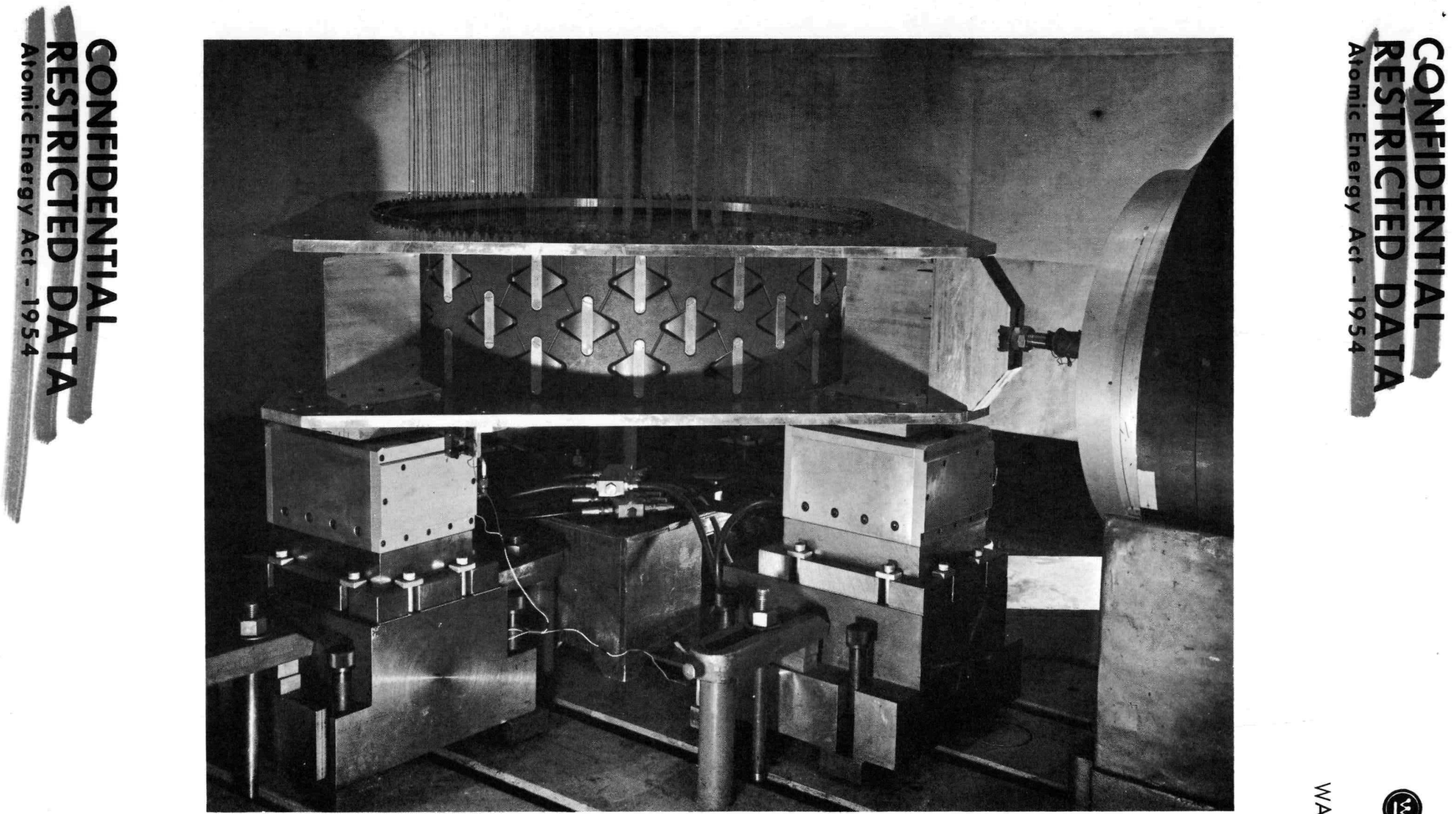

I

FIGURE 1

Test Setup

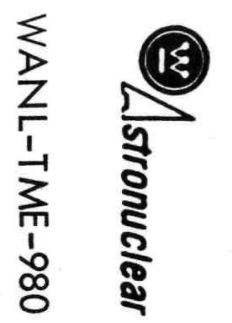



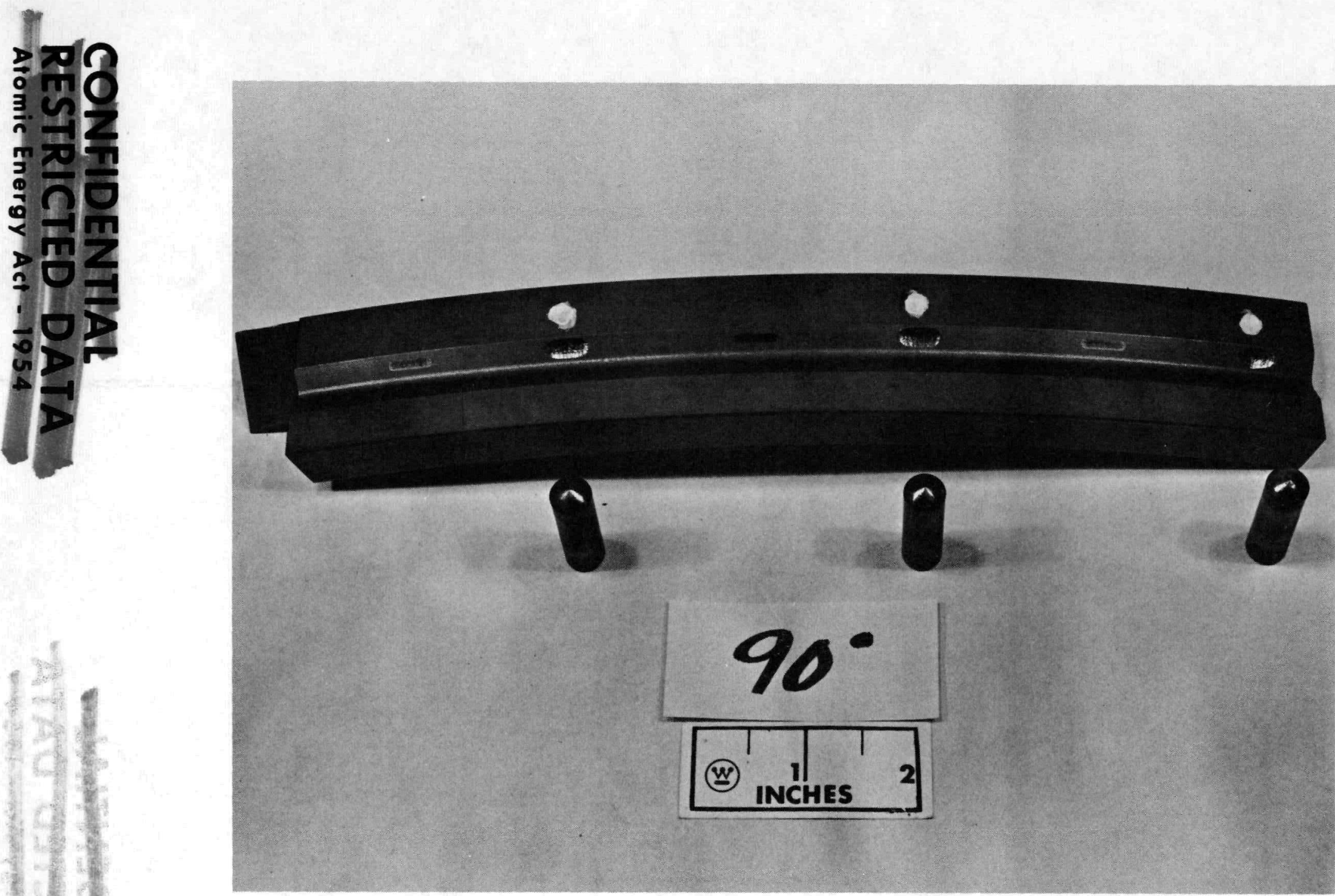

FIGURE 2

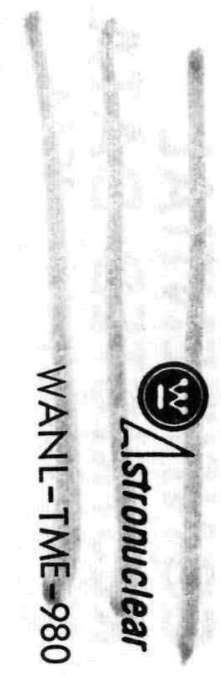

